\title{
ピエゾ極限センサを用いた雪崩発生計測柵の性能試験
}

\author{
下井 信浩*1, 中正 和久 ${ }^{* 2}$, Carlos CUADRA ${ }^{* 3}$, 間所 洋和 ${ }^{* 1}$
}

\section{Performance test of avalanche measurements fence using piezoelectric limit sensors}

\author{
Nobuhiro SHIMOI ${ }^{* 1}$, Kazuhisa NAKASHO ${ }^{* 2}$, Carlos CUADRA $^{* 3}$ and Hirokazu MADOKORO ${ }^{* 1}$ \\ ${ }^{{ }_{1},{ }^{*} 3}$ Department of Systems science and Technology, Akita Prefectural University \\ 84-4 Ebinokuchi, Tsuchiya, Yurihonjo-shi, Akita 015-0055, Japan \\ ${ }^{* 2}$ Graduate school of Sciences \& Technology for innovation, Yamaguchi University \\ 2-16-1 Tokiwadai, Ube-shi, Yamaguchi 755-8611, Japan
}

Received: 27 May 2018; Revised: 3 July 2018; Accepted: 4 September 2018

\begin{abstract}
Under certain weather conditions, avalanches can occur because of snow cover on a steep slope. Such avalanches can reach snow fences that are arranged as countermeasures. Furthermore, traffic is completely blocked when fences collapse and snow falls on a road. Therefore, prediction of avalanche occurrence is important, but such predictions are considered difficult. To resolve this difficulty, this study assessed measurement of the danger degree by measuring the risk to the avalanche fence at the time of snowfall and falling rock according to changes in the load and the impact of voltage proportional to the avalanche barrier deformation. This measurement system has fixed sensors attached with mounting brackets to a dedicated avalanche prevention measurement fence. It measures the pressure and vibration measurement of the snowfall at the time of avalanche or rock fall occurrence at the main structure of the fence. Furthermore, this fence made of lumber from thinned timber is useful as a defensive barrier countermeasure against avalanches and falling rock. It is designed to withstand a snow load of 3-5 [ $\mathrm{t} / \mathrm{m}^{2}$ ] during an avalanche.
\end{abstract}

Keywords : Smart sensor, Piezo electric sensor, Snow accumulation measurements fence

\section{1. 緒 言}

わが国の豪雪地帯では雪崩災害が後を絶たず，昭和56，59，61年には集落にて多くの死傷者が出る大災害とな った. 平成3〜27年の25年間では雪崩発生件数135件，死者数221人の被害も発生している（総務省，2017）. 主要幹線道路付近の斜面や危険度の高い急斜面には多くの雪崩防止柵や防止林などの予防工が構築されているが, 大雪時には予防工設備が積雪に埋没して雪崩発生時の抑制効果が薄まる可能性がある. 斜面の除雪や気象状況と 雪崩の履歴などを参考にした危険度の掌握による, 雪崩の多発生地帯の巡回や警備が実施されているが，す心゙て の急斜面や危険地帯における実施は困難である。雪崩警報システムとしては，ワイヤの切断により雪崩発生を検 知する方法（佐藤他，2016）や積雪・降雪強度などの気象データ解析による雪崩危険度評価方法（上石，2004） が用いられている。 また，ドップラーレーダーを用いた速度計測方法（佐藤他，2016）や地震計による雪崩発生 時の地盤振動の計測方法（上石，2004, Leprettre et al., 1998, 和泉, 小林，1986）, また,振動センサによる雪崩通 過時のポールの振動計測方法（飯倉他，2000）, 定点カメラを用いた画像解析システム（花岡, 2008）等のハイテ ク機器による計測も実施されている.

\footnotetext{
No.18-00244 [DOI:10.1299/transjsme.18-00244], J-STAGE Advance Publication date : 13 September, 2018

*1 正員，秋田県立大学システム科学技術学部（テ015-0055 秋田県由利本荘市土谷字海老ノ口 84-4)

*2 山口大学大学院創成科学研究科（干755-8611 山口県宇部市常盤台 2-16-1）

*3 秋田県立大学システム科学技術学部

E-mail of corresponding author: shimoi@akita-pu.ac.jp
} 


\section{2. 雪崩検出柵を用いた新計測技術}

雪崩検出システムの警報による通行車両の進入禁止や周辺住民の強制避難のためには，誤作動なく確実に雪崩 発生を検知しなければならない.さらに，設置箇所の多くが険しい山間部であるため，現場施工に関する顧慮や 安全確保の問題も累積している. また, 通行止めや避難実施時には, 運転者の安全確保や避難者の一時収容施設 も必要となるため，雪崩問題への予算確保についても困難が予想される．高額の計測システムは設置にも制限が 生じるため, 簡易的かつ工費が安価である雪崩計測システムを構築しなければ安全安心の社会の実現は遠く及ば ないと考えている.

\section{$2 \cdot 1$ 現状の雪崩計測技術の問題点}

雪崩発生の予知に関しては，気象条件や地形条件から求められたセンサの選定を実施しているが，予測精度の 不安定さに問題が生じている. そのため, 雪崩発生の予兆や動態を観測するためのシステム化が求められている. 現場で使用されているセンサには, 雪崩の挙動を直接的に検知する方法ではワイヤロープ方式や振動センサ方式, 雪崩の挙動を間接的に検知する方法では画像処理方式や地震計方式がある. 各センサの概要と問題点を説明する と，(1) 振動センサ : 加速度計が内蔵された FRP(Fiber-Reinforced Plastics)のポールを用いたセンサによって，計測 したパルス信号と雪崩規模の関係から段階的な警報の発令が可能となっているが，一回の雪崩で使用が不可能と なる（上石，2004）。（2）ワイヤセンサ : 設置したワイヤロープの振動による電気的な信号をキャッチ寸るシステ ムであり, 安価なことが利点となっているが雪崩以外の風や動物の通過による誤りの振動による警報も問題とさ れている. (3) 画像検知システム : 画像解析による雪崩の発生状況と予測を診断寸る方式である. 天候や昼夜の区 別等で検知結果が大きく左右されることやリアルタイムに画像情報を解析する技術に欠けていることも大きな欠 点であると思われる. (4) 地震計による計測システム : 地震計を岩盤に挿入して雪崩発生時の地盤振動の大きさで 判断する方式が存在するが，大掛かりな作業が難点となっている. 他にも研究段階の計測技術が存在するが，ど の技術も一長一短であることから問題点が多く見受けられる．さらに，計測技術にも共通した課題であるが，雪 崩危険斜面の多くは山間部の険しい地域にあり, 商業電源の設置工事や重機等を使用した大掛かりな敷設工事は 困難であることが予想されることにある（佐藤他，2016）。

\section{$2 \cdot 2$ 雪崩計測方法の比較}

本研究で考案した間伐材を利用した雪崩計測柵を図 1(a)に示す．雪崩計測柵は，およそ縦 3360×横 3800×高さ $3350 \mathrm{~mm}$ であり, 数基設置すれば良いと考えている. 図 1(b)のように中央部にピエゾ極限センサ（図 2 に示す才 リジナルのセンサ）を専用金具で固定し，下部にデータ送信用の無線通信機器を配置した．本センサは衝撃や積 雪による計測柵のダメージの大きさに比例してセンサ自らが電圧を出力するため, 計測用電源を必要としない. また，通信機器には野外観測で実績のある応用地質株式会社製の i-SENSOR を用いている．計測柵の破壊試験で 得られた值からマイコンによる閾值設定をし, 閯值以上の出力電圧に対してのみ送信を行っており, 大容量通信

（サンプリング周波数 $10 \mathrm{~Hz} ）$ と電力消費（20mW/h）を考慮して約 1 年間の通信を確保している．欠点は計測柵 の大きさと重量であるが，山間部においても使用可能な様に組立て施工による簡略化と運搬を考慮した設計をし ている. また，雪崩が予測される急斜面において，複数の計測柵が設置可能な場合には雪崩発生の抑止力になる と考えられる，さらに，設置した計測柵の間を雪崩が通り抜けてしまうような誤検知を防止する役割もあると思 われる. 他方, 簡易的で有効な雪崩計測方法として考えられる技術にファイバー状のチタン酸ジルコン酸鉛セラ ミックスをフイルムで挟んだシート状にしたもの MFC (Micro Fiber Composite) を利用した計測技術が存在する. 衝撃荷重と出力電圧に相関関係があり計測が可能であることと, 寒冷地でも出力差が小さいという利点がある. 報告書ではこの MFC をポリウレタン製の円筒内部に接着して雪崩の衝撃荷重を検出している（佐藤他，2016）. しかし, 設置箇所によっては 50〜100 本程の計測杭からの大容量データを短時間で処理する必要があるため, セ ンサ設置の労力と大容量データの時系列処理および危険度の優先順位などの決定において誤検知が生じると予想 される. 


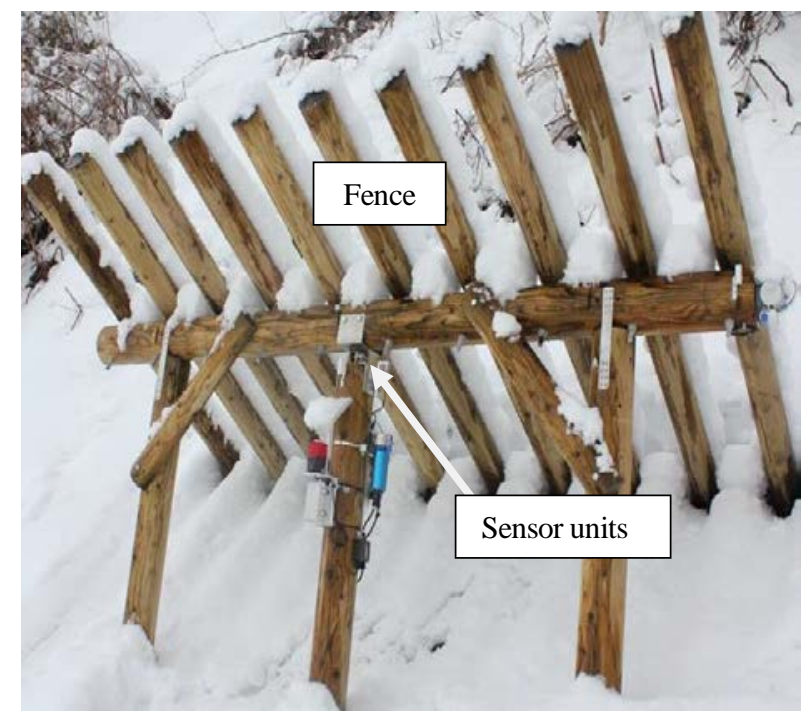

(a) Measurement fence

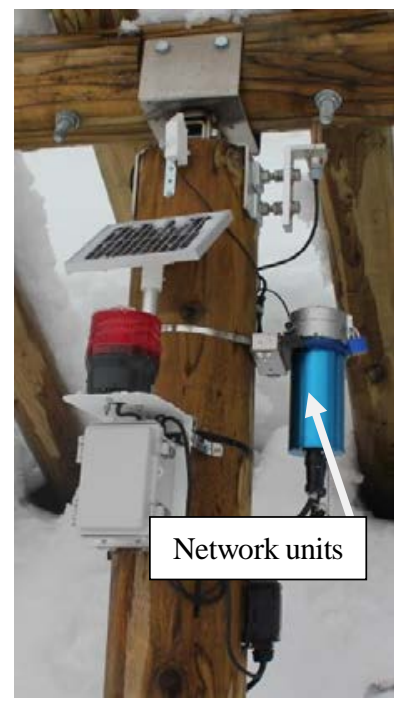

(b) Radio systems set

Fig.1 Photographs of the avalanche fence for measuring. A measurement fence using lumber from thinned timber devised for this research is approximately $3360 \mathrm{~mm}$ long $\times 3800 \mathrm{~mm}$ wide $\times 3350 \mathrm{~mm}$ high. The equipment installation situation shown in Figure1(a) depicts one set of a piezo-limit sensor and piezo vibration sensor fixed in the central part with dedicated metal fittings in Figure1(b). Radio communication equipment for data transmission is arranged in the lower part. When transmitting the measurement result, the threshold value is set by the microcomputer from a value obtained from destructive testing of the measurement fence and its components. Information communication of unnecessary sensor output voltages is not set.
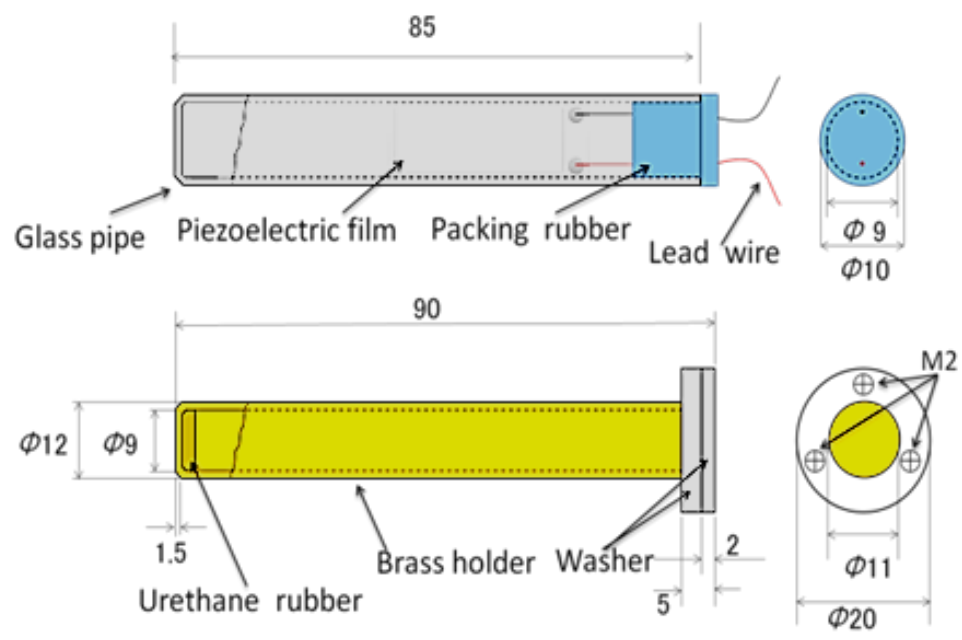

Fig.2 Structure of piezoelectric limit sensor. Presents details of the piezo limit sensor used for measuring static load. The piezoelectric limit sensor shown in Figure is a piezo film (DT-2-028k / L; Tokyo Sensor Co., Ltd.), which is fixed tightly in a rigid glass tube using ultraviolet curing (UV) urethane resin. After inserting the lead wire with a hole in the rubber topper of the packing rubber, a connector is added for connection to the external cable. This glass tube is inserted into the metal holder with a gap for tolerance. The holder used for the sensor exterior can be changed to aluminum, brass, iron, or a similar material depending on the object to be measured. For sensors used in this test, a brass exterior was selected

\section{$2 \cdot 3$ 計測技術の構築}

雪崩の検知には雪崩の衝撃と積雪による沈降圧を直接計測する必要がある．雪氷の塊が落下することも考慮し た安価な大型柵の設置により，「計測」および「雪崩の抑制効果」を可能にすることが望ましい.

図 2 にガラス管の破損時のみ荷重を計測するピエゾ極限センサを示す．ピエゾ極限センサは，ピエゾフィルム

（東京センサ製 DT2-028K/L）（東京センサ，2001）を硬質ガラス管の中に紫外線硬化樹脂（UV）を用いて密着固 定したものである.ウレタン製のパッキンゴム栓にリード線を挿入後，外部ケーブルと接続するコネクタを付加 
した.このガラス管を常用はめ合い程度の公差によるギャップで金属ホルダに挿入して使用する。センサ外装に 使用するホルダの材質は，本計測の雪崩以外の構造物にも使用が可能なように，アルミ，真鍮，鉄材などに変更 が可能である．本試験に用いたセンサは真鍮の外装を選択した．破壊に応じてセンサ本体がせん断または圧壊な どにより破損し，この加力に応じてガラス管内部のピエゾフィルムが変形することから，計測柵が受けたダメー ジに応じた電圧による出力を可能としている. 出力電圧の発生時に, 雪圧荷重により計測柵の破壊が始まる応力 や完全破壊に至る変位を求めることができる.

\section{$2 \cdot 4$ 最大加力の試験方法}

実装試験前に研究所内において基本特性試験を実施した．計測柵が斜面に設置した状態と同様になるよう，図 3(a)のように架台に試験用計測柵を固定し，油圧ジャッキによる引込み力を使用して逆向きの方向で載荷する方 法を用いた．縦柵（垂直支柱）に油圧ジャッキによる引張を発生させ，支柱部などの加力方向の変形状況，セン サ応答，荷重を計測し比較した，変位計は各接合部分および梁（図 3(a)：(1)水平方向の木材）の変形量を計測す るために設置した．図 3(a)，(b)に示すように，ピエゾ極限センサは中央部垂直支柱の接合部の専用金具（センサ 取り付け用ブラケット）に挿入して固定し, 加力と変位によるピエゾ極限センサの出力関係を時系列に計測した （下井他，2013）.

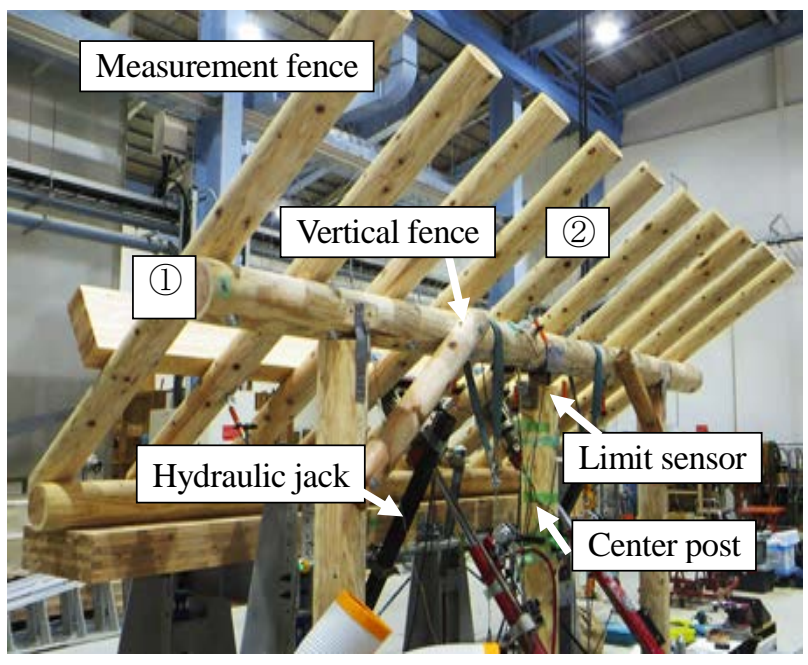

(a)Measurement fence by thinned wood

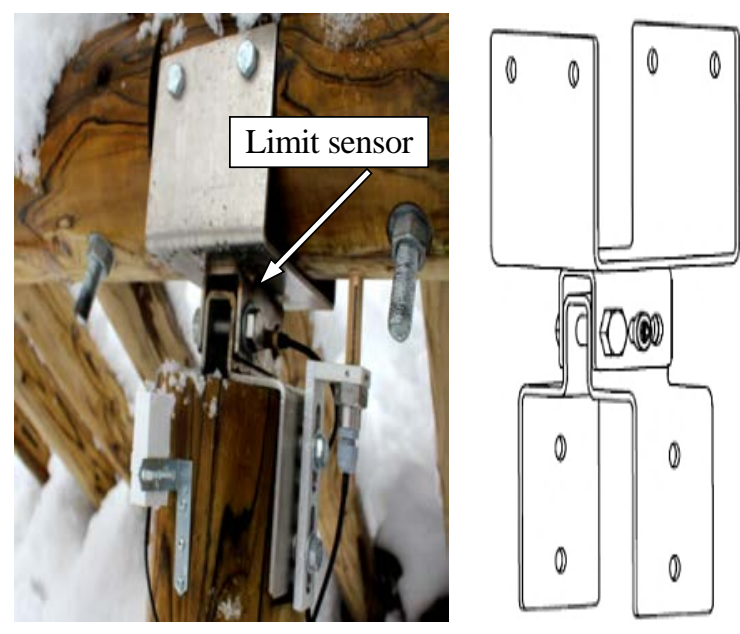

(b)Sensor setup and limit sensor bracket

Fig.3 Photographs of the measurement fence and sensor bracket shape. portrays the metal fence shape and the sensor bracket. Before the mounting test, a basic characteristic test was conducted using a hydraulic jack in the laboratory. We used a method of loading in the opposite direction using the retraction force of a hydraulic jack so that the measurement fence is the same as that when installed on the slope. We devised a test method using a test measurement fence and a cradle like that in Figure 3(a), generated a tensile load on the vertical fence, measured the support post deformation, the sensor response, and the load, and compared the results. The displacement gauge was installed to measure the amount of deformation of each joint part and beam. As shown in Figure 3(b), the sensor mounting bracket and the piezo-limit sensor were inserted and fixed in the sensor holder portion, which is a dedicated metal fitting of the center post connecting portion.

\section{3. 積載荷重を想定した加カによる計測柵の性能評価結果}

計測柵は，札幌市中山峠の平成 24～26 年の積雪 $2 \mathrm{~m}$ 程度（総務省信越総合通信局,2017）における降雪荷重から 計算して設計製作した（高橋他，2016）。計測柵の中央部に負荷される最大許容加力が 50〜 70[kN]で完全破壊す る公算である. 屋内試験の結果, 加力の増加と共に梁の左右両方向への変位も発生した. 図 4(a)はこの変位とピ エゾ極限センサ出力の関係を示し, 図 4(b)に加力とピエゾ極限センサ出力の関係を示す. 図中の楕円部(1)付近で 荷重が約 $20 \mathrm{kN}$ 時にピエゾ極限センサから最初の大きな電圧出力が認められた. このとき, 中央部の垂木 (図 3(a) : (2)上部斜めの木材) における変位は，約 10～15mm を計測していることから，この值を超えると設計時の安全許 
容内における最初の破壊が生じた瞬間であると考えられる。つぎに楕円部(2)付近で約 $45 \mathrm{kN}$ のときに 2 回目の大 きな電圧出力が認められた. このときの垂木の変位は 18〜20[mm]程度である. 完全破壊である楕円部(3)付近で約 70[kN]のときに 3 回目の大きな出力を示し, 中央部の垂木変位も 30〜35[mm]の大きな值を示してその後, 計測柵 は完全に破壊された．本計測柵を 2 基製造して 2 回試験を行った結果，同様の結果が得られたことから再現性が あると考えている，なお，測定結果において，ピエゾ極限センサ出力と加力計測器による值に遅れが生じて実際 の計測柵の破壊状況と異なっている理由は, 両計測器のサンプリング周波数が異なるためである. ピエゾ極限セ ンサは，ガラス管とピエゾ素子を組み合わせて金属製の保護管内に挿入した構造である，通常（健全時）はガラ ス管内に封入されたピエゾ素子は固定されているため，センサの出力は計測されないが，設計上の安全值を超え る変位や荷重が生じた場合, 負荷荷重によりガラス管が部分破損し, その衝撃および金具の変動によりピエゾ素 子から電圧出力がある。これらの結果から，本センサは 3 段階による計測柵の危険状況をリアルに知らせること が可能であると考えられる.つまり，1回目の出力で注意を促し，2 回目の出力を検知した場合は直ちに危険を予 知する必要があることを示している. さらにセンサ出力は当初計測柵の設計時における最大許容荷重の数值内に て実証することが可能であったことからも信頼性が伺えると思われる.

屋内試験結果の検証のために野外で実施した試験状況を図 5(a)に示寸. 斜面に設置した計測柵において, クレ ーンを用いて 500[kg]の土襄を 5 トンまで載荷する加力試験を実施した. 屋内試験で得られた加力および変位デ 一タから想定した検知範囲の設定が妥当であるか検証した. 図 5(b)は, 載荷加力とピエゾ極限センサ出力の関係 を表している．図中の楕円部(1)付近において約 10[kN]でダメージを示す信号が，中央部の楕円部(2)付近において 約 30[kN]で危険信号が，楕円部(3)付近において約 50[kN]弱で破壊を示寸限界信号が認識された. 図 4 に示した同 様の屋内試験結果と比較すると,ダメージ信号は約 20[kN], 危険信号は約 45[kN]付近であり, 限界信号は約 65[kN] 付近で計測されている．両計測柵の各所要信号に差が生じた点は，実験に使用した計測柵が各々異なることにあ ると考えられる. しかし，屋内試験で使用した破壊加力が約 70[kN]である計測柵と野外試験で使用した破壊加力 約が 50[kN]の計測柵から求められた各々の信号出力時における加力比(0.7)を積算すると, 同様の信号特性が得ら れていることが判断される. 図 4(a), (b)および図 5(b)の異なる計測柵から得られた計測結果を考察すると, 大き な変位や大きな加力の変化に対して計測柵のダメージに対応したセンサ出力が得られていると判断でき, 本セン サの信頼性が得られていると考えられる.

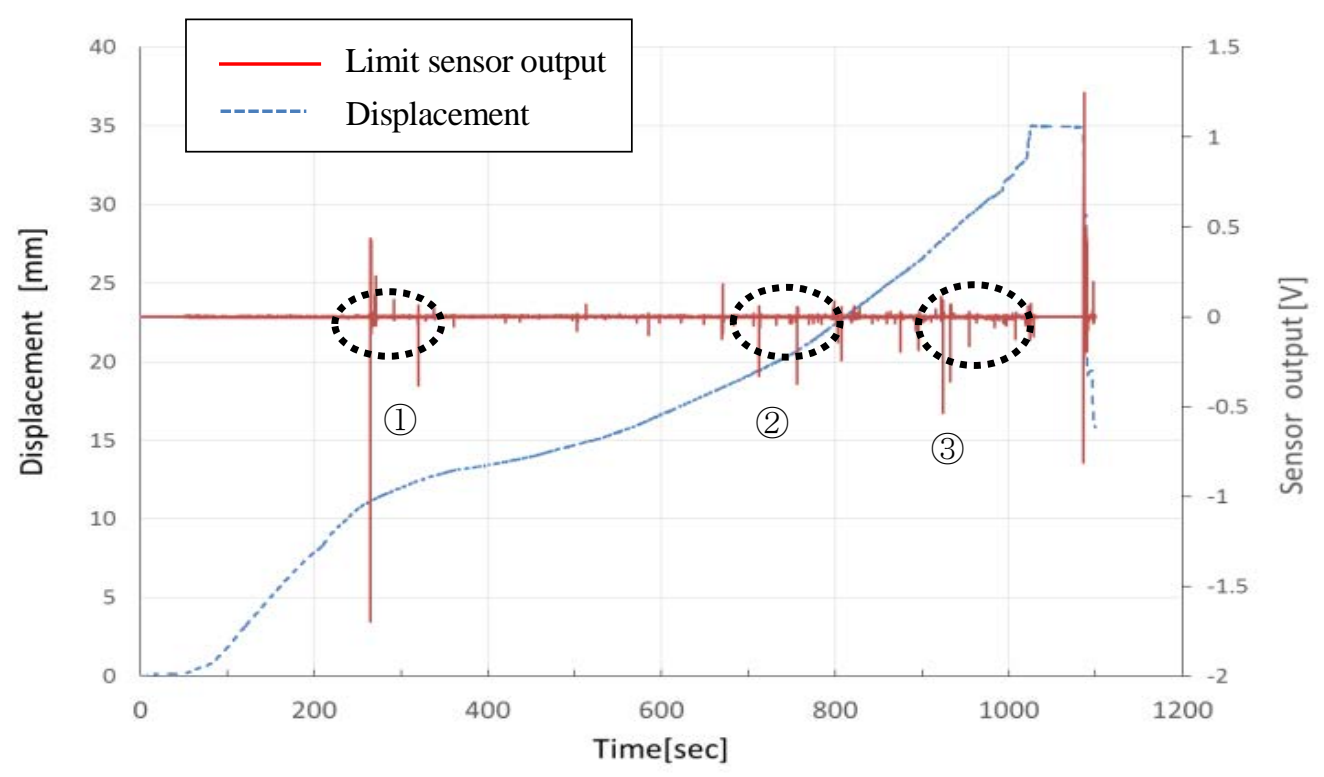

(a)Relation displacement between Limit sensor output.

(1)Beginning of destruction, (2)Complete destruction warning, (3)Complete destruction 


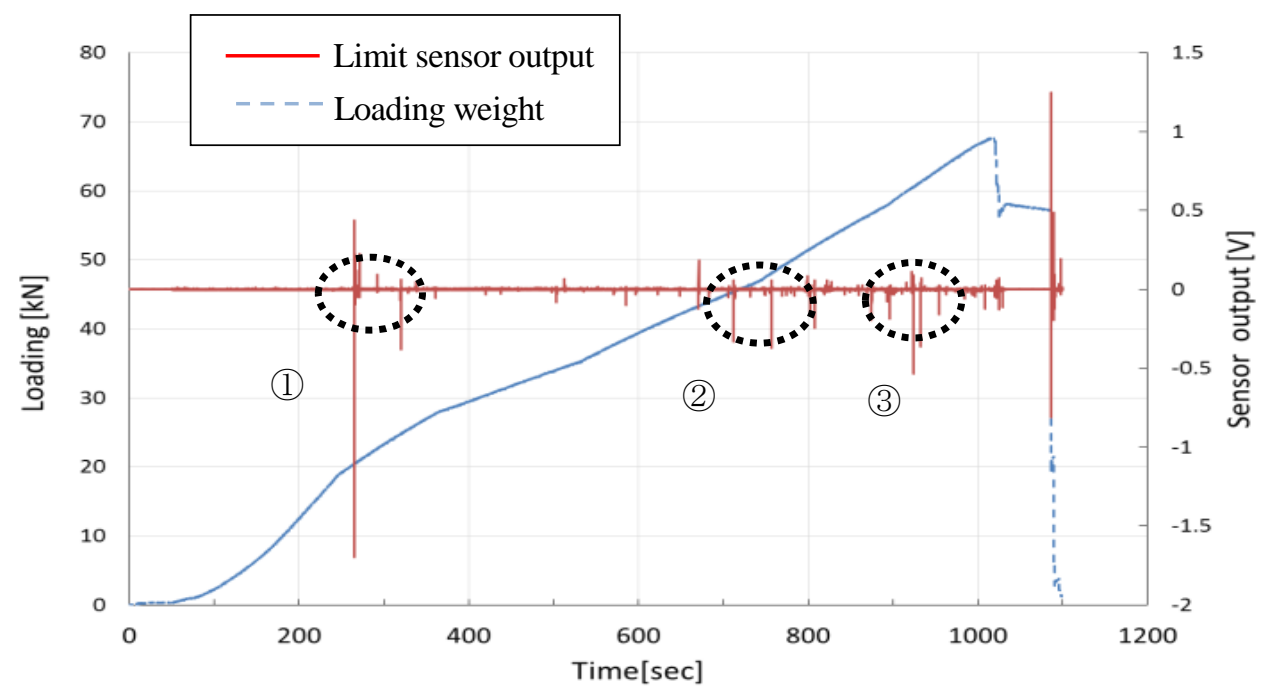

(b)Relation loading weight between Limit sensor output.

(1)Beginning of destruction, (2)Complete, (3)Complete destruction

Fig.4 Relation of loading and output voltage of piezoelectric limit sensor in avalanche measurements fence. Depicts the relation between displacement and the piezo limit sensor output. Figure 4(b) shows the relation between applied force and the piezolimit sensor output. According to the test results, the beam displacement occurred as the load increased. The first large voltage output was recognized from the piezo-limit sensor at about $20[\mathrm{kN}]$ near the elliptical part shown in Figure 4(a). Because the rafter displacement at the central part at this time measures deformation of about 10-15 mm, it is regarded as the moment when the first destruction occurred within the design permission in the measurement fence. Next, in the vicinity of the ellipse (2) in the figure, the second large voltage output is recognized when it is about $45[\mathrm{kN}]$. At this time, the displacement of the rafter shows deformation of about $18-20 \mathrm{~mm}$. When it is about $70[\mathrm{kN}]$ near the elliptical part (3) in this drawing, which is complete destruction, the sensor shows the third large output and the rafter displacement in the center shows a large value of 30-35 [mm], and the measurement fence is completely destroyed.
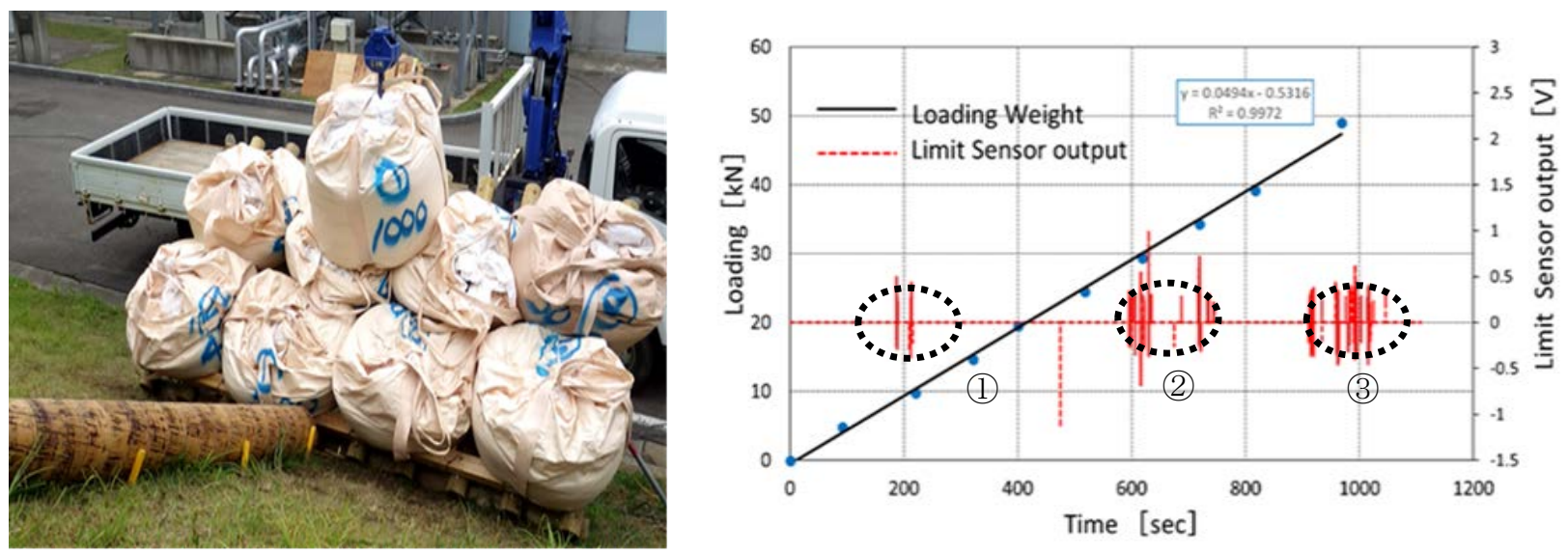

(a) Photograph of portrays loading on the fence

(b) Relation loading weight between piezoelectric limit sensor output.

Fig.5 Relation loading weights between piezoelectric limit sensor output . (a)Photograph of portrays loading weights (b) Relation loading weight between piezoelectric limit sensor output. A signal indicating damage at a load of around 10 [kN], a danger signal at around $30[\mathrm{kN}]$, and a limit signal indicating breaking at a weakness of less than $50[\mathrm{kN}]$ were recognized.

\section{4. 結 語}

雪崩などの対策工事がされていない無防備の急斜面における「予防工」と「計測」を兼ね備えた計測柵のシス テムを考案した。間伐材を有効利用した本計測システムは安価であり, 雪崩の発生などの有無を自律的に観測し て周辺の住民や通行車両に注意を促すことが可能である. 本計測システムは, 火山性ガスの発生する山岳地域に 
おいても計測柵の本体は，間伐材の構造であるため腐食の心配は少なく，計測装置のみをガスや雨水等から保護 寸れば良いため利便的であると考える.

\section{文献}

花岡正明, 雪崩・地すべり研究センターにおける雪崩常時現地観測システム, 砂防学会誌, Vol.60, No.5 (2008), pp.78-82.

飯倉茂弘, 河島克久, 遠藤徹, 藤井俊茂, 振動センサを利用した雪崩発生検知システムの開発, 日本雪氷学会誌, Vol.62, No.4 (2000), pp.367-374.

和泉薰, 小林俊一, 地震計に記録された表層雪崩, 災害科学復興研究所（新潟大災害研年報）, No.8 (1986), pp.99104.

上石勲, センサを用いた雪崩の検知・予知技術, 日本雪工学会誌, Vol.20, No.3 (2004), pp.294-297.

総務省信越総合通信局, 山岳・雪崩等遭難者電波探索システムのための周波数有効利用技術に関する調査検討山

岳・雪崩等遭難者電波探索システムのための周波数有効利用技術に関する調査検討報告書 (2017), pp.1-3.

佐藤亮太, 高橋大介, 飯倉茂弘, 仮設型雪崩検知装置の開発, 鉄道総研報告, Vol.30, No.3 (2016), pp.17-22.

下井信浩, Carlos H. CUADRA, 間所洋和, 西條雅博, 簡易ピエゾケーブル変位センサと有限要素法を用いた伝統木 造構造物の振動解析, 日本機械学会論文集 C 編, Vol.79, No.806 (2013), pp153-163.

株式会社＼cjkstart東京センサ, 製品ナビ, ピエゾケーブル, R1 (2001), pp.17-18.

高橋涉, 原田裕介, 松澤勝, 北海道における雪崩予防柵の設計の妥当性について, 国土交通省北海道開発局 第59 回（平成 27 年度）北海道開発技術研究発表会 (2016), available from $<$ http://thesis.ceri.go.jp/db/documents/public_giken_list/2015/>, (参照日2018年3月10日) .

\section{References}

Hanaoka, M., Avalanche always onsite observation system at snow avalanche and landslide research center, Japan Society of Erosion Control Engineering, Vol.60, No.5 (2008), pp.78-82 (in Japanese).

Iikura, S., Kawashima, K., Endou, T. and Hujii, T., Snow avalanche detection and alarm systems using a vibration sensor, The Journal of the Japanese Society of Snow and Ice, Vol.6, No.4 (2000), pp.367-374 (in Japanese).

Izumi, K. and Kobayashi, S., The movement of a powder snow avalanche as recorded on a seismography research institute for natural hazard \& disaster recovery, No.8 (1986), pp.99-104 (in Japanese).

Kamiishi, I., Technology of avalanche control using the sensor, Japan Society Snow engineering, Vol.20, No.3 (2004), pp.294297 (in Japanese).

Ministry of internal affairs and communications, Survey consideration report on frequency effective utilization technology for mountainous and avalanche-encounter person radio search system, Survey study report (2017), pp.1-3 (in Japanese).

Sato, R., Takahashi, D. and Iikura, S., Development of portable type avalanche detector, RTRI Report, Vol.30, No.3 (2016), pp.17-22 (in Japanese).

Shimoi, N., Cuadra, C. H., Madokoro, H. and Saijyo, M., Vibration analysis of wooden traditional frames using finite element method and measurements with a simple piezoelectric cable displacement sensor, Transactions of the Japan Society of Mechanical Engineers, Series C, Vol.79, No.806 (2013), pp.153-163 (in Japanese).

Tokyo Sensor Co., Ltd. Piezoelectric cable/ Piezo film technology manual, R1 (2001), pp.17-18(in Japanese).

Takahashi, W., Harada, Y. and Matsuzawa, M., On the validity of the design of avalanche prevention fences in Hokkaido, Ministry of Hokkaido development bureau, Hokkaido Development Technology Research Presentation, No.hu-2 (2016), available from <http://thesis.ceri.go.jp/db/documents/public_giken_list/2015/>, (accessed on 10 March,2018) (in Japanese). 